\title{
The Concept of Rights and Protection to Employees: A Comparative Overview
}

\author{
RAJA RAZIFF RAJA SHAHARUDDIN*, ABD HAMID ABD MURAD, \\ LUKMAN ABDUL MUTALIB \& HASNIZAM HASHIM ${ }^{1}$
}

\begin{abstract}
Issues relating to the rights and protection accorded to employees throughout their employment with the employers is a matter that has been given much attention and treated with utmost priority in any organization, be it in the public or the private sector. It is an undeniable fact that the success story of any organization in the generation of profits in its enterprise or the smooth running in achieving the organization's desired objectives is much attributed to having a reliable, skilled and efficient workforce. Today, employees have been regarded as one of the most valuable assets of any organization. In pursuant thereto, apart from having various employment packages, laws regulating employment were enacted as protective measures in guiding both employers and employees. At the international level, rights and protections to employees have been embedded in the Universal Declaration of Human Rights. Comparatively, under the Shariah, though a similar concept has been forwarded, the notion of employment has been elevated to the status of 'ibadah. Islam places importance of adhering to the Shari'ah principles in dealing with protection accorded to employees. As employment is regarded as 'ibadah' the employees are required and enjoined to observe full dedication, sincerity and commitment to their tasks. It is the responsibility of the employers, on the other hand, to ensure that the welfare of their employees is well protected. This paper attempts to outline the concept of employment under the Shari'ah and civil perspectives and to provide a comparative understanding on the rights and protection accorded to employees.
\end{abstract}

Keywords: Employee Rights, Human Right, Protection to Employees, Shari'ah

While it is the duty of the employees to work according to their terms of reference, it is also an undeniable fact that the employers have a corresponding responsibility to provide adequate protection to their employees. Protection to employee and their rights are clearly embedded under Articles 23 and 24 of the Universal Declaration of Human Rights (UDHR: 23-24). Article 23 provides that everyone has the right to work, to free choice of employment, to just and favorable conditions of work and to protection against unemployment. Employees under the same Article has been accorded without any discrimination, the right of equal pay for equal work and in terms of

\footnotetext{
${ }^{1}$ Raja Raziff Raja Shaharuddin*(Corresponding author), Lecturer at Faculty of Syariah and Law, Universiti Sains Islam Malaysia, Bandar Baru Nilai, 71800 NILAI, Negeri Sembilan, Email: rraziff@usim.edu.my; Abd Hamid Abd Murad, Senior Lecturer at Faculty of Syariah and Law, Universiti Sains Islam Malaysia, Bandar Baru Nilai, 71800 NILAI, Negeri Sembilan, Email: hamid@usim.edu.my; Lukman Abdul Mutalib, Ph.D., Senior Lecturer, Faculty of Syariah and Law, Universiti Sains Islam Malaysia, Bandar Baru Nilai, 71800 NILAI, Negeri Sembilan, Email: lukman@usim.edu.my; Hasnizam Hashim, Lecturer at Faculty of Syariah and Law, Universiti Sains Islam Malaysia, Bandar Baru Nilai, 71800 NILAI, Negeri Sembilan, Email: hasnizam03@gmail.com.
} 
remuneration worthy of human dignity supplemented if necessary by other means of social protection. Article 24 provides that employees have the right to rest and leisure, including limitation of working hours and periodic holidays with pay. All these provisions are not new under the Islam. This article will attempt to elucidate that the concept of rights and protection that is accorded to employees under the civil law structure have long been enjoined by the Shari'ah.

\section{Concept and Framework of Employment Under the Civil Law}

Laws governing employees' rights and protection in Malaysia can be found under the Employment Act 1955, Industrial Relations Act 1967, Employees Social Security Act 1969, Employees Provident Fund Act 1991, Occupational Safety and Health Act 1994 and Trade Unions Act 1959. An employee is defined under Section 2 of the Employment Act (Law of Malaysia, act 265) as "any person or class of persons (a) included in any category in the First Schedule to the extent specified therein; or (b) in respect of whom the Minister makes an order under subsection (3) or section 2A". In the situation where an offer of employment is made by an employer to a prospective employee, the said offer being duly accepted by such person or persons, the laws governing the relationship between an employee and employer commences.

The Employment Act 1955 basically regulates the contract of service of an employment contract in the private sector by laying down the basic and minimum terms and conditions of the employment contract, setting out work, weekly rest day, public holidays, annual, medical and maternity leave as well as termination and lay off benefits. It must, however, be observed that the said Act applies only to those with earning not in excess of RM1500 per month or for those who are in the manual labor occupation (Act 265: 2\{1\}). The Industrial Relations Act 1967, unlike the Employment Act 1955, offers a wider scope of application. It applies to all employees be it from the private or the public sector as defined under Article 132 of the Malaysian Federal Constitution and no limit is imposed in regards to the type of occupation.

\section{Concept and Framework of Employment Under the Shariah}

Under the Shari'ah there exist no regulations on employment in a codified manner. Basically, all issues were attended through the divine revelation of the Quran and Sunnah. Thus, the need to have codified employment laws did not arise then. Employment were relied upon the principle of 'ubudiyyah (total submission to Allah), mas'uliyyah (accountability) and itqan (determination). Based on these principles the people were taught that the main purpose of employment apart from earning livelihood, was to seek the pleasure of Allah. The main objective of the "employees" was to seek the pleasure of Allah which was enjoined by Allah in Surah al-Dzariyyat verse 56 which provides that "I created the jinn and humankind only that they might worship Me". With this direction in mind, the employees have the responsibility to work with sincerity and not to enter into wrongful personal gains in discharging their duties and be fully aware that they will accountable for their acts. Allah has promised rewards for goodness and punishment for wrongful acts be held in this world or the hereafter.

In Islam, the employer and the employee should regard one another as brothers in faith and not as master and slave. When the employer regards his employee as his brother in seeking the pleasure of Allah, he would be very much concerned with the welfare of his employee including paying of good wages, so that the employee might be able to cover all his necessary expenses. On the other hand, the employee will take special interest in his work and will be willing to work to the best of his ability and strength. As a result, business would prosper to the advantage of both the employer and the employee and the national wealth would also increase. The Holy Prophet Muhammad SAW always advised his companions to treat their servants well (Afzal-ur-Rahman 
1995: 246-247). It is reported that the Prophet SAW said: "Give food and clothing to the servants and slaves and do not impose such burden (work) on them that they cannot bear, For if it is impose to theme provide assistance (Baihaqy 1408H: Bab 26 Fi al-Ihsan Ila al-Mamalik: Hadis no. 80)

From the above hadis it is clear to us that the Shari'ah's concept of employer-employee relationship is firmly rooted in the bond of a brotherhood spirit and is inspired by it ( / حبل من الناس) الإحسان / التعاون. In other words, Islam or the Shari'ah prescribes brotherhood of which the owner and the worker are members. A brother cannot rest in peace when he sees his own brother in distress; the same thing applies to employer-employee relationship (Hakim 1972: n54). The Shariah aims at maintaining justice and fair play in all the facets of human life (Hakim 1972: n95) It should be noted that the basic source of an employer or employee's rights and obligations is found in the contract of service or contract of employment. The basic source of employers' rights would be the documents setting out the terms and conditions of employment. The right to dismiss an employee is the prerogative of the executive bodies of the employee's workplace, but the dismissal must be done according to the legal process (Shaikh Mohd Saifuddin 2001). Therefore, all agreements, whether oral or written, must be clear and transparent. The agreements must be just and lawful. Employees should know their duties and responsibilities and they should be told their rights in terms of vacations, leaves, compensations, etc (al-Maidah 5:1). The Prophet SAW said:'Muslims must abide by their agreements, unless there is an agreement that makes halal what is haram or makes haram what is halal' (Baihaqy 1344H: Bab Syurut Fi al-Nikah: Hadis no. 14820).

By virtue of this fact, an employee, who by his own free will, signs a contract between himself and an employer to perform a certain job, should fulfill the agreement according to Shari'ah principles. As a contract of employment involves duality of performance, in which the employee is required to produce good or render services, the employer, in the same spirit, should also respond with the appropriate reward in compensation (Abdullah Mohammad Seidu n.d.: 4).

The Shari'ah allows all human beings the right to enter any lawful profession or occupation and to conduct any lawful trade or business. The workers should be treated with dignity and honor. No work is menial or degrading. The Prophet SAW kissed the hands of a laborer who showed him his rough hands due to his hard labor. He prayed for him and spoke very highly of those who labor over against those who sit idle or go begging. The Shari'ah teaches that workers should be treated with kindness (al-Nisaa 4:36-37) Under the Shariah law (Hakim 1972: 100), i.e. the worker cannot be forced to accept a work or job against his will; he should not be burdened with excessive load of work which is beyond his capacity; the employer owner should regard a worker not as a plaything, obeying his will but as a free man, who is his equal, and; the employer should specify beforehand to employee the nature of his duties and how the employer conduct his businesses and make his profit.

Prophet Muhammad SAW said, "Your brothers are your responsibility. Allah has made them under your hands. So whosoever has a brother under his hand, let him give him food as he eats and dress as he dresses. Do not give them work that will overburden them and if you give them such task then provide them assistance". (Asqalany 1407H: Kitab al-'Itq: Bab Qaul al-Nabiy s.a.w al-'Abid Ikhwanukum: hadis no. 2545). The above Hadith clearly lays down (Afzal ur Rahman 1995: 247249) certain principles among which are:

1. The employer and the employee should regard one another as brothers in Faith (Ihsan) (or brothers in humanity in the case of non-Muslims) and not as master and slave. When the employer regards his employee as his brother (merely to seek the pleasure of God), he would be very generous in paying him good wages and at the same time giving him his rights. On the other hand, the employee would take special interest in his work and work hard to the best of his ability and strength. As a result, business would prosper to the advantage of both employer and the employee. 
2. The employer should be on the same level with his employee at least in the basic human needs. In other words, the employee should be given reasonable wages which high enough to cover their needs. The words of the Holy Prophet SAW "should feed him from that he eats and give him clothes the like of which he wears". This saying of the Prophet provides the fundamental principle which determines the minimum wages of the laborers. It demands from the Muslim employers that they should be very generous to their employees in giving wages which should be high enough to meet their economic demands according to the needs of the times. The reason is because the employees have worked and help the employers to the position of prosperity which now they enjoy, in return, they have the right to claim from them equitable remuneration to meet their customary requirements.

3. An employee should not be given too heavy or difficult task which is beyond his capacity, or is likely to put him in great hardship in doing it; and that he should not be made to work for long hours that might affect his health. In other words, the nature of work both from the point of view of physical capacity and time, should not be too burdensome for him. If an employee is given a difficult and burdensome task, he should be assisted with more employee and capital in order to render his task less difficult. Besides, he must be adequately compensated in the form of extra remuneration for difficult jobs and longer hours of work. The Prophet Muhammad SAW said " None of you will be a perfect believer, until you wish for your brother Muslim what you wish for yourself "(Baihaqy 1408H: Bab 32 Fi al-Mukmin Yuhibb Li Akhihi al-Mukmin Ma Yuhibb Li Nafsih: Hadis no. 90), "God has no mercy on him who is not merciful to (His) men "(Syaibany 1991: Bab Abu 'Amr Jarir b. Abdullah. Hadis no. 2527) , Be merciful to those on earth, that (God Who) is in Heaven will be merciful to you" (Naisabury 1990: Kitab al-Tawbah Wa al-Inabah: hadis no. 7631).

The Shari'ah law stresses that any amount of work done, must receive its rightful value. It is because fairness and justice demands that any piece of work performed must be rewarded according o its merit without being undervalued or overvalued (Tahira n.d.: 13). In other words, the Shari'ah strongly detests and condemns robbing an employee of his/her wages as well as delay in paying the wages by an employer. Employers are therefore obliged to pay employees on time, because withholding of wages owed to employees is against the Shariah teachings. Denying a worker his right to his wages is considered deprivation, which is considered a denial of his rightful compensation of wages for his hard labor (Tahira n.d.: 13)

The determination of wages must be fixed somewhere between the minimum and the maximum level determined by the customary standard of living and contribution of the employees respectively (Afzal ur Rahman 1995: 251). The Islamic state, at the same time has a legal right to interfere and fix the minimum wage according to the needs of the time.The Caliphs of the Holy Prophet SAW. had also clearly laid down the principles initiated by the Holy Prophet for fixing the wages of Government servants. Many factors were taken into account in determining the wages; besides the ability of the worker, the nature of his work and his economic responsibilities were also given due consideration (Afzal ur Rahman 1995: 254). Saidina 'Umar, the second caliph, for instance stated few points in determining the amount of grants and allowances (Afzal ur Rahman 1995: 253): What services has a person rendered to the cause of Islam?; What hardship has a person undergone, or is undergoing for Islam?; How long a person has served Islam?; What are the real (i.e., actual) needs of a person?, and; What are the economic responsibilities of a person (i.e., the size of his family)? 


\section{Comparative Concepts}

Employment in Islam covers a wider scope compared to the concept under the civil law. Under the Islamic concept, employment is not only effort by an employee to secure a livelihood, but at the same time considered a holy obligation which if done well will be rewarded not only in this world but also in the hereafter. The concept of reward as seen under the Islamic purview is not seen under the civil law which emphasis solely on the relationship between mankind whereby the rewards is only seen in the form of salary or wages given for services rendered by the employee.

Under the employment law in Malaysia, it is the implied responsibility of the employer not to direct the employee or cause him to do be done any act which is against the law as seen in the case of Gregory vs. Ford ([1951] 1 AER 121). Under the Islamic concept, this aspect has not been stressed upon only to the employers, but more importantly in relation to employee themselves to earn a living through righteous ways. In the case of Tomlinson vs. Dick Evans ([1978] ICR 639) the court decided contract of service could not be enforced if the employers and employees had knowledge of wrong doings. In Islam a similar aspiration is evident. Such contracts are not enforceable and persons executing the wrongdoings will be reprimanded by Allah. Thus even though one escapes punishment under the eyes of the law, such acts will still be accounted for in the hereafter. In Finch vs. Telegraph Construction and Maintenance Co. Ltd ([1949] 1 AER 452) it was decided that employers shall be responsible for injuries suffered by the employee in the course of duty. It is the responsibility of the employers to undertake reasonable measures to protect their employees from risks in the execution of their tasks during employment. This common law principle is also enunciated under the Islamic ambit.

In the modern era, the employers bear full responsibility in providing for safe working environments for its employees. In Malaysia, the Occupational Safety and Health Act 1994 was legislated to complement the existing provisions of law on work safety and health and shall take prevalence in view of any contradictions. This Act provides a legislative framework to initiate and encourage a high standard in safety and health at workplace. The coming into force of this Act directly create the employer statutory responsibility in ensuring the safety and health of its workers. It is a requirement under the Act for employers to provide safety measures in accordance with the latest known practices and standards to prevent job hazard occurrences during the employee discharging his/her duties.

The Occupational Safety and Health Act 1994 through the Department of Occupational Safety and Health has given serious attention to the issue of stress and violence at work place by introducing the Guidance for the Prevention of Stress and Violence at the Workplace. Under this guideline, the employers and employees are encouraged to adhere to the said guideline in the elimination and control of stress and violence at the workplace. The case of Walker vs. Northumberland County ([1995] 1 AER 737) acknowledged the necessity of the employers to conduct an assessment of the risk of stress at work place and to formulate policies and programs in the management of stress. It was decided in this case that the employers could not pledge ignorance to mental health risk resulting from stress at workplace.

The issue of stress at the workplace has been covered much earlier in Islam. Employers are enjoined to regard their employees as their family or relative and on that note to give good treatment to them. This practice in itself minimizes the issue of stress at the workplace among employees. The family tie relationship between employers and employees allows for a good platform in holding a discussion on problems faced by the employees. Under the civil law the position is somewhat different in the sense the existing relationship between employer and employee resemble more to the relations of master with his servant. This master and servant relationship in itself creates a clear barrier to achieving harmonious environment, hence leading to 
aggravation of stress at the workplace due to the inability of employees in communication or airing job related plights, problems or grouses to the employers.

Sexual harassment is a prevalent menace at work place irrespective of gender. Till today there are no specific laws on sexual harassment. Nevertheless, the Ministry of Human Resource has issued a code known as "Kod Amalan Mencegah dan Membasmi Gangguan Seksual di Tempat Kerja" (Code of Practice on the Prevention and Eradication of Sexual Harassment in the Workplace) to encourage employers to create a domestic mechanism to prevent or overcome and eradicate sexual harassment at work place. Among the steps suggested in the said code are: policy statement by the Management of prohibition against sexual harassment at the workplace; the definition of sexual harassment is made known clearly to the management and the staff of the organization; to provide for procedure of complaints of sexual harassment; disciplinary rules and punishment against the perpetrators; measures to protect victims sexually harassed, and; programs on prevention and education.

In Islam, this aspect has been treated from the very beginning. To avoid or minimize the said problem, Islam in principle has made it mandatory for the women to cover their aurah against non-muhrim. The act of covering the aurah in accordance to the Islamic dress code has been further blended with the prohibition against uncontrolled and free interaction between men and women and has been adapted in the workplace. This said prohibition having direct impact on the behavior of both parties, employers and employees, hence serve as a means of the prevention sexual harassment especially in the workplace. Islam has acknowledged the rights of employees 1,400 years ago, long before unions were established to protect employees' rights. Viewing the acknowledgment of the rights of employees, from civil perspectives, it can be said that the provisions do not differ too much from the Shari'ah provisions. However, the emphasis in the Shari'ah is on the concept of work as 'ibadah. Both laws share the same ideals in the employees' protection of rights, but the Shari'ah concept of employees' protection is more comprehensive based on Divine revelation and Prophetic traditions. Indeed, it was part of Prophet Muhammad's teaching to encourage work and to assure basic rights for all categories of workers whether employees or day laborers. Workers should be treated with dignity and honor regardless of the kind of work they are performing, as long as this work is lawful. It is believed that if this concept of 'employer-employee' relationship practiced and adhered to, it would provide an ideal model for initiation and sutainment of productive outcomes in the management of human capital.

\section{References}

Al-Quran.

Abdul Majeed.1985. The Last Prophet and His Teachings. Pakistan: PIDC Printing Press.

Abdullah Mohammad Seidu. n.d. Islamic Concept of Employer-Employee Relationship. An Instrument For Managing Human Resources And Certain Operational Risk Exposures http://islamiccenter.kau.edu.sa/arabic/Hewar_Arbeaa/abs/PDF-Hiwar3/242.pdf. retrieved from web site on 10 Oct 2013.

AER -The All England Law Report. n.d. London: Lexis Nexis Butterworth.

Afzal-ur-Rahman. 1995. Economic Doctrines of Islam. Vol. II. 4th ed. Lahore: Islamic Publications (Pvt.) Limited.

Asqalany Ahmad b Ali b Hajar. 1407H. Fath al-Bari. Cairo: Maktabah al-Salafiyyah.

Baihaqy, Abu Bakr Ahmad b Husayn b Ali. 1344H. Sunan al-Kubra wa fi Zaylihi al-Jawhar al-Naqiy. Heidar Aabad: Majlis Dairat al-Ma'arif al-Nizamiyyah al-Kainah Fi al-Hind

Baihaqy, Abu Bakr Ahmad b Husayn b Ali. 1408H. al-Arba'un al-Sughra. Beirut: Dar al-Kitab alAraby. 
Hakim Mohamed Said. 1972. The Employer and The Employee Islamic Concept. $1^{\text {st }}$ ed. Pakistan: The Time Press.

Hammudah Abdalati. 1998. Islam in Focus. Petaling Jaya: Islamic Book Trust.

ICR-Industrial Cases Report. n.d. The Incorporated Council of Law Reporting for England and Wales.

Kod Amalan Mencegah dan Membasmi Gangguan Seksual di Tempat Kerja Malaysia. http://jtksm.mohr.gov.my/index.php?option=com_content\&view=article\&id=123\%3Akodamalan-mencegah-dan-membasmi-gangguan-seksual-di-tempat-kerja\&catid=63\%3A gangguan-seksual\&Itemid=550\&lang=en on 10 Oct 2013.

Law of Malaysia, Act. 265. Employment Act 1955. Retrieved from web site on 10 Oct 2013 http://www.agc.gov.my/Akta/Vol.\%206/Act\%20265.pdf.

Maududi, Abu Al-A'la. 1993. Human Rights in Islam. London: The Islamic Foundation.

Naisabury Muhammad b Abdullah Abu Abdullah al-Hakim. 1990. Al-Mustadrak 'Ala al-Sahihayn. Beirut: Dar al-Kutub al-Ilmiyyah.

Shaikh Mohd Saifuddeen Shaikh Mohd Salleh. n.d. Work As An Act of Worship. Retrieved from Website: http://www.ikim.gov.my/index.php/ms/the-star/7061-work-as-an-act-ofworship on 10 Oct 2013.

Syaibany Ahmad b 'Amr b Dahhak Abu Bakr (1991) al-Aahaad Wa al-Mathany. Riyadh: Dar alRayah.

Tahira Bahsarat. n.d. The Characteristic Features of Worship as Propounded by Islam (an analytical study). Ph.D Thesis. Retrieved from Website: http://pu.edu.pk/images/journal/szic/ previousissue_pdf/3-Tahira\%20Basharat.pdf Retrieved on 10 Oct 2013.

The Universal Declaration of Human Rights. http://www.un.org/en/documents/udhr/ at 30 Sept 2013. 